Working Paper

in Economics and

Development Studies

Department of Economics

Padjadjaran University

No. 201314

\title{
TWENTY YEARS OF EXPENDITURE INEQUALITY IN INDONESIA, 1993-2013
}

Arief Anshory Yusuf ${ }^{1}$

Andy Sumner ${ }^{2}$

Irlan Adiyatma Rum ${ }^{1}$

${ }^{1}$ Center for Economics and

Development Studies CEDS

${ }^{2}$ King's International Development

Institute, King's College London

September, 2013

Center for Economics and Development Studies, Department of Economics, Padjadjaran University Jalan Cimandiri no. 6, Bandung, Indonesia.

Phone/Fax: +62-22-4204510

http://www.ceds.fe.unpad.ac.id

For more titles on this series, visit:

http://econpapers.repec.org/paper/unpwpaper/ 
TWENTY YEARS OF EXPENDITURE INEQUALITY IN INDONESIA, 1993-2013

Arief Anshory Yusuf, Andy Sumner and Irlan Adiyatma Rum

Abstract: In this article, we consider the recent increase in inequality in Indonesia. We make new, consistent estimates of expenditure inequality for 1993-2013, using several measures that draw on household expenditure data from the National Socioeconomic Survey (Susenas) for 1993-2013. In doing so, we note that the central statistics agency, Badan Pusat Statistik (BPS), used grouped data for its estimatesof inequality until 2009 and that this underestimated inequality up to then. Thus the rise in inequality reported since 2009 actually has a longer history. We argue that Indonesia experienced divergence and convergence at the same time: the magnitude of the rise in inequality was significant (divergence), but the rise was greatest in provinces or districts with low initial levels of inequality (convergence). We consider the literature on drivers of changes in inequality and identify a set of hypotheses, with an empirical basis, which we introduce as potential Indonesian-specific drivers of rising inequality for future exploration.

Keywords: inequality, Gini, Theil, distribution

JEL code: D63 


\section{INTRODUCTION}

Inequality in Indonesia has recently become more visible in the public policy debate because the Gini coefficient has risen to the highest point ever reported by Badan Pusat Statistik (BPS), the central statistics agency. In light of this, we consider a set of indicators of expenditure inequality between 1993 and 2013, in order to assess the significance of this rise across a range of measures.

As is well known, expenditure survey data, such as those from Indonesia's National Socio-economic Survey (Susenas), understate income (and asset) Inequality because they ignore savings, for example, while top incomes largely elude surveys (see, for details, Leigh and Van der Eng 2010). These are inherent shortcomings of all such surveys, not just Indonesia's, and Cornwell and Anas (2013) note ongoing attempts by BPS to address them. Unmeasured expenditure, too, is a serious concern in Susenas and similar surveys; Nugraha and Lewis (2013) find that inequality is much lower once non-market income is considered (In contrast, non-market consumption is already included in Susenas).

If one reviews existing studies of inequality in Indonesia, there are two points worth noting: First, some studies argue that expenditure inequality was relatively low before the 1997-98 Asian financial crisis and had not increased notably as a result of economic growth—in short, growth has been distributionally neutral (Akita, Kurniawan, and Miyata 2011; Hill 2008; Hill, Resosudarmo, and Vidyattama 2008; Van der Eng 2009). However, others argue that inequality was relatively high or rising even before the crisis (Frankema and Marks 2009; Leigh 
and Van der Eng 2010; Van Leeuwen and Foldvari 2012). Second, a number of studies have argued that intragroup, urban-to-rural inequality and interregional inequality have increased since the crisis (Akita 2002; Akita and Miyata 2008; Sakamoto 2007; Skoufias 2001; Suryadarma et al. 2005, 2006).

\section{NEW ESTIMATES OF EXPENDITURE INEQUALITY, 1993-2013}

\section{2a. Methodological Approach}

We make new estimates of the evolution of expenditure inequality in Indonesia for 1993-2013, using data from Susenas. ${ }^{1}$ To establish patterns in the data, we estimate the following indicators of inequality: the Gini coefficient (using individuals' data); the decile dispersion ratio of the average consumption of the richest $10 \%$ of the population to the average consumption of the poorest $10 \%$; and the interregional disparity by the Theil index of interprovincial inequality and interdistrict inequality. We decompose inequality by different subgroups of population and by region, using the decomposition technique of Haughton and Khandker (2009). This makes it possible to estimate the contributions of urban and rural inequality and interprovincial disparity to total inequality.

\section{2b. The Lorenz Curve and Gini Coefficient}

\footnotetext{
${ }^{1}$ Susenas is a series of large-scale multi-purpose socio-economic surveys initiated in 1963-64. Since 1993, Susenas surveys have covered a nationally representative sample of around 200,000 households. Each survey contains a core questionnaire (which consists of a household roster requesting the gender, age, marital status, and educational attainment of household members), supplemented by modules that cover about 60,000 households, rotated over time, and collect additional information on, for example, health care and nutrition, income and expenditure, and labour force activity (Surbakti 1995).
} 
Our estimates suggest that Indonesia’s Gini coefficient, using individuals' data, rose from 0.36 to 0.41 between 1993 and 2013 (figure 1). If we were to use grouped data (the 10 consumption deciles), as BPS did prior to 2009, we would find that this estimate would be lower. BPS has not published its exact approach to estimating inequality, as far as we know. If we were to group the data into 10 deciles, we would produce observations close to but not the same as those published by BPS. Given that grouping the data degrades the estimates, we prefer to use individuals'data. Figure 2 shows the shifts in the Lorenz curve from 1993 to 2003 to 2013 - as the curve shows inequality fell between 1993 and 2003 and then rose between 2003 to 2013(by more than it had fallen in the preceding decade).In short, the inverse of the Kuznets Curve (that inequality rises in the early stages of development and then falls).

We find that the Gini coefficient was stable, if not decreasing slightly, before the 1997-98 crisis. After the crisis, however, the Gini coefficient showed a strongupward trend in both urban and rural areas, as well as across regions in Indonesia,such as in Java and in the non-Java islands (figure 3). Indonesia's Gini rose by32\%, from 0.32 in 2003 to 0.43 in 2013. In rural areas it rose by $30 \%$, from 0.25 in 2003 to 0.32 in 2013. This trend is slightly stronger in rural areas outside Java than those in Java. Our provincial- and district-level analysis captures a pattern of convergence (see figure 4): the rate of increase in the Gini coefficient tended to befaster in provinces with initially low inequality, and vice versa. ${ }^{2}$

\section{2c. Top Incomes and the Decile Dispersion Ratio}

\footnotetext{
${ }^{2}$ The regression of the change in the Gini coefficient as a function of its initial level confirms the convergence at both district and provincial level. The coefficient of the initial value is negative and statistically significant at the $1 \%$ level.
} 
The decile dispersion ratio is the ratio of the mean expenditure of the richest $10 \%$ of households (as captured in Susenas) to that of the poorest $10 \%$ of households. ${ }^{3}$

Figure 5 shows the development of the decile dispersion ratio from 1993 to 2013 for Indonesia, urban areas, rural areas, Java, and non-Java regions. Between 1993 and 2013, the decile dispersion ratio declined moderately prior to the 1997-98 crisis, fell further during the crisis, and increased rapidly after the crisis up to 2013.

The trend in the decile dispersion ratio over the last decade suggests that Inequality rose more notably than that made visible by the Gini coefficient (figure 5 versus figure 3). From 2003 to 2013, for example, the decile ratio for Indonesia rose by $63 \%$, or 0.46 points, every year, which is triple the 0.13 -point-a-year rise from 1990to 1997. The rising decile dispersion ratio is more prominent in urban areas and inJava: in urban areas the gap between the richest $10 \%$ and the poorest $10 \%$ widened by around $69 \%$ between 2003 and 2013. In rural areas the gap between the top and bottom income groups also grew significantly, albeit more slowly.

\section{2d. Interregional Inequality}

The final dimension of income disparity in Indonesia that we consider is interregional inequality, of which the Theil index is one of the most common measures.

We calculate it here for both interprovincial inequality and interdistrict inequality.

The result is shown in figure 6. The estimates suggest that, for each year, interregional

\footnotetext{
${ }^{3}$ For analysis of top incomes see in particular Leigh and Van der Eng's (2010) study.
} 
inequality was always higher among districts than among provinces. Yet the data show that interregional disparity has not increased over the last 20 years if one takes the period as a whole. However, the decline in the 1990s and the rise in the 2000s are especially noticeable at the district level. (figure 6). ${ }^{4}$

\section{2e. The Contribution of Between- and Within-Group to Inequality}

The discussion so far, on different indicators of inequality, suggests that inequality in Indonesia has risen rapidly in the last 10 years, after having been somewhat stable, and even declining slightly, prior to the 1997-98 crisis. There are also some measures of inequality,such as the generalised entropy index, that can be decomposed into inequality of individual households within one particular group and inequality within those particular groups. For example, looking at figure 7, we can say that inequality in Indonesia in 2013 was driven primarily (93.7\%) by within-province inequality. Inequality between provinces contributed only $6.3 \%$ to overall inequality. Similar patterns are evident between urban and rural areas. Inequality between urban and rural areas contributes only a small proportion (5.8\%) to inequality in Indonesia. The largest contribution comes from inequality within urban and rural areas.

Looking at the trends in the share of inequality between provinces and between urban and rural areas, we find that the data suggest that the contribution of inequality between provinces and between urban and rural areas has declined

\footnotetext{
${ }^{4} \mathrm{We}$ also calculated the ratio of mean expenditure per capita between Java and non-Java, and between the non-eastern and eastern regions of Indonesia. The ratio for non-eastern to eastern regions was always higher than that of Java to non-Java, because Indonesia's eastern region is still lagging in economic development. The gap changed little in the first part of the period, but it narrowed during the most recent period. This is more or less consistent with the development of the Theil index, but there was a greater convergence in the ratio near the end of the period. In sum, it is clear that the gap between more and less developed regions in Indonesia has narrowed gradually over the last 10 years.
} 
consistently since 1993. Conversely, the contribution of inequality of individual households within provinces and within urban and rural areas has increased consistently(figure 7). The explanation for this trend, drawing on the earlier discussion, is simply that rising inequality in Indonesia since 2003 has been common or uniform across geographical locations, whereas the gap between regions has been either consistent or decreasing slightly in more recent years.

\section{THE DRIVERS OF CHANGES IN INEQUALITY IN INDONESIA}

\section{3a. The Pattern of Economic Growth}

One proximate cause of increasing inequality in Indonesia is the pattern of economic growth. Table 1 shows the growth rate in real per capita expenditure during four periods: the last period, 2003-13, represents the post-crisis and reformasi era. We calculate the growth rate in annual real expenditure per capita for different poverty lines and consumption percentiles (to avoid determinism): the mean of the population, the median of the whole population, the poor as defined by the national poverty line, the poor as defined by the $\$ 2$-a-day moderate international poverty line (2005 PPP dollars), and several consumption percentiles. ${ }^{5}$

Looking at growth during 1993-2013, we see that while the growth rate in expenditure per person of the mean of population was $3.7 \%$ per year, the growth rates of the national poverty line and the $\$ 2$ a day poor were $3.0 \%$ and $3.2 \%$, respectively. In other words, by the national poverty line the expenditure per capita

\footnotetext{
${ }^{5}$ On international poverty lines, see Sumner and Edward (2014).
} 
of the average population grew $22 \%$ faster than that of the poor, and grew $15 \%$ faster by the $\$ 2$-a-day, moderate international poverty line.

The 'pro-poorness' of growth has worsened since the start of the reformasi era. By the national poverty line, during 1990-1996, in the pre-reformasi era, the growth of the average population was $77 \%$ faster than the growth of the poor; during 2003-13 the growth in expenditure per capita of the mean average population was more than twice (2.1 times) the growth rate of the poor (5.4\% vs $2.6 \%)$. For the period 1990-96 the annual average growth rate of expenditure per person (in real terms) was $3.5 \%$ ayear-or $37 \%$ faster than that of those living on less than $\$ 2$ a day, at $2.6 \%$ a year.In the reformasi era, however, the annual average growth rate of expenditure per person in the average population was $97 \%$ faster than that of those living on less than $\$ 2$ a day. In short, there is a big difference between the two periods.

\section{3b. Potential Drivers of Inequality in Indonesia}

The global literature has identified a set of factors that drive expenditure inequality (see UNDP 2014 for a recent substantial review of conceptual and empirical literature). One way of grouping these factors is into exogenous and endogenous drivers. The former relate to shifting global trade and finance patterns and technical change; the latter to macroeconomic policies, labour market polices, wealth inequality, fiscal policy (taxation and transfers), and government spending on public goods. ${ }^{6}$

\footnotetext{
${ }^{6}$ This resonates with Piketty (2014), and the argument that it is inequality of asset and wealth
} 
The causes of recent changes in inequality in Indonesia are complex, but it is possible to identify a set of specific factors, with sufficient empirical evidence, that would be worthy of future exploration. In Indonesia, exogenous examples of these factors relate to trade. For example, Indonesia experienced a commodity boom in coal and palm oil during 2000s, in particular, which may have increased inequality. Coal production more than tripled and palm oil production quadrupled during 2000-11 (Burke and Resosudarmo 2012, 318). Yusuf et al. (2013) use a computable general equilibrium model to show that the commodity boom increased inequality but that those changes in inequality were due to world prices of mining commodities rather than those of estate crops. ${ }^{7}$

Suryahadi, Hadiwidjaja, and Sumarto (2012) note that changing sectoral contributions to growth are associated with slowing poverty reduction, and thus potentially with changes in inequality. The commodity boom hypothesis could be advanced to explain the widening gap between poor and rich groups within rural areas.

During more or less the same period (as discussed above), there has been a rise in the prices of commodities - particularly of Indonesia's traditional export commodities, such as estate crops. These estate crops are grown mainly in rural areas and owned by rural landowners. The richer rural households will benefit disproportionately from this boom. We can see the signs of this mechanism at work

ownership that has driven increasing within-country inequality around the world. This may also have been the case in Indonesia. Leigh and Van der Eng $(2009,197-98)$ briefly discuss the distribution of wealth in Indonesia. Davies et al. (2009) offer the only estimate of wealth distribution in Indonesia (which is based on the 1997 Indonesia Family Life Survey).

${ }^{7}$ The price changes of estate crops still affect positively low income households because many of those households include members who are employed as plantation workers. 
by comparing inequality in rural areas in Java and non-Java regions, because most estate crop plantations are outside Java. A second exogenous factor related to trade is that of rice prices, which rose by $20 \%$ during $2003-5$ after having been stable for a long period. Inequality also spiked during 2003-5, and although there are several possible reasons for this spike, the increase in domestic rice prices may have reduced the real expenditure of the poor.

Endogenous drivers of expenditure inequality in Indonesia include changes in the labour market and in fiscal policy. Yusuf et al. (2013) argue that changes in the formal labour market, including interrelated changes in labour market regulation-an increase in severance payments, the strengthening of labour unions, rising minimum wages, reduced demand for unskilled labour, and greater informality in low-wage employment-have increased inequality. Growth of formal employment was rather stagnant in the last decade, owing to slow growth in the manufacturing sector. Before the 1997-98 crisis, the manufacturing sector was the primary source of Indonesia's economic growth. During 1990-96, for example, the sector's GDP growth was $11.2 \%$ (while average economic growth was $7.9 \%$ ) and its employment growth was $6.0 \%$ (while average national employment growth was only $2.3 \%$ ). Almost a decade after the crisis, employment growth in the manufacturing sector seems to have halted. While its growth for the period 20002008 was almost the same as the national average (4.7\%), its employment growth was only $0.9 \%$. The formal manufacturing sector has historically been a haven for people in rural areas looking for better-paying jobs. When such opportunities are limited, there is an excess of unskilled labour in rural areas (prior to the Lewis turning point). As the rural labour market is more flexible, overall rural real wages will be 
pushed down, increasing inequality in rural areas. The official data from BPS suggests that real wages for agricultural workers have been declining for the past few years, possibly indicatingthat people are constrained from migrating to cities in search of for malemployment (Manning and Pratomo 2013).

Large transfers, notably rice and fuel subsidies, are other endogenous drivers worthy of exploration. Since the 1997-98 crisis, increasingly large fuel subsidies have curtailed the fiscal space for additional government social spending. Since 2000, they have been $10 \%$ to $25 \%$ of central government spending (Howes and Davies 2014, figure 4). It is well known that the impact of the fuel subsidies on incomes has been strongly regressive; they benefit the rich disproportionally more than the poor (Agustina, Fengler, and Schulze 2012). The government increased retail fuel prices several times, in 2005, 2008 and 2013, but over time inflation eroded the price hikes (Howes and Davies 2014, figure 5). To mitigate the impact of the price hikes, the government distributed cash transfers to the poor and near poor. For example, the 2005 policy package most likely contributed to the decline in the Gini coefficient from 2005 to 2006 (Yusuf and Resosudarmo 2008). But, partly due to rising international oil prices, the fuel subsidy has remained very large and it is likely that its regressive effect has sustained and increased inequality since 2003. There are of course other factors one could note may well have played a role in changes in inequality (not least fiscal decentralisation and/or the creation of more districts) but we have only included in the discussion here those which we currently have some empirical basis.

\section{CONCLUSION}


We have analysed the evolution of expenditure inequality in Indonesia between1993 and 2013 in order to discuss the significance of the recent rise in expenditure inequality. More specifically, we have asked whether inequality in Indonesia increased over the period across a range of inequality measures - and, if it did,how rapidly — and the extent to which regional, provincial, and urban and rural differences shaped the overall pattern and the extent to which these components drove the overall trend.

Our consistent estimates suggest that inequality in Indonesia has been rising significantly. However, the rise in inequality is predominantly visible in the period after the 1997-98 crisis, or the reformasi era of political reform and democratisation. Before the crisis, inequality was relatively stable and moderate if not declining. The magnitude of the more recent rises in inequality is startling. Furthermore, rising inequality is more or less common across regional dimensions, urban and rural areas, and Java and non-Java regions.

We think that BPS's estimates of inequality before 2009 underestimated inequality, owing to the use of grouped data; the rise in inequality reported since 2009 therefore has a longer history. Indonesia is experiencing both divergence and convergence at the same time; the magnitude of the rise in inequality is significantyet the change in inequality has been greatest in provinces or districts with low initial levels of inequality. We propose a set of hypotheses, not necessarily mutually exclusive, that may play an important role in explaining rising inequality in Indonesia. We present these hypotheses, based on initial empiricalwork, for future exploration. The recent 
commodity boom may influence urban and rural inequality, but this is not clear.

Rigidity in the formal labour market maybe significant, and the evidence for this is clearer. It is likely that rice prices and cash transfer programs have contributed to changes in inequality because of their relative impacts on the living standards of the poorer groups of the population versus their impacts on those of better-off groups, all of which suggests that a better understanding of the drivers of changes in inequality in Indonesia is essential to help public policy better address rising inequality in Indonesia. 


\section{REFERENCES}

Akita, Takahiro. 2002. 'Regional Income Inequality in Indonesia and the Initial Impact of the Economic Crisis'.Bulletin of Indonesian Economic Studies 38 (2): 20122.

Akita, Takahiro, and Sachiko Miyata. 2008. 'Urbanization, Educational Expansion, and Expenditure Inequality in Indonesia in 1996, 1999, and 2002'.Journal of the Asia Pacific Economy 13(2): 147-67.

Akita, Takahiro, Puji Agus Kurniawan, and Sachiko Miyata. 2011. 'Structural

Changes and Regional Income Inequality in Indonesia: A Bidimensional

Decomposition Analysis'.Asian Economic Journal 25 (1): 55-77.

Agustina, Cut Dian R.D., Wolfgang Fengler, and Günther G. Schulze. 2012. 'The

Regional Effects of Indonesia's Oil and Gas policy: Options for Reform'. Bulletin of Indonesian Economic Studies 48 (3): 369-97.

Burke, Paul J., and Budy P. Resosudarmo. 2014. 'Survey of Recent

Developments'.Bulletin of Indonesian Economic Studies 48 (3): 299-324.

Cornwell, Katy, and TitikAnas. 2013. 'Survey of Recent Developments'.Bulletin of Indonesian Economic Studies 49 (1): 7-33.

Davies, James B., Susanna Sandstrom, Anthony Shorrocks, and Edward Wolff. 2009.

‘TheGlobal Pattern of Household Wealth'.Journal of International Development 21:

$1111-24$.

Frankema, Ewout, and Daan Marks. 2009. "Was It Really "Growth with Equity” under Soeharto? A Theil Analysis of Indonesian Income Inequality, 1961-2002'. Economics and Finance in Indonesia 57 (1): 47-76.

Haughton, Jonathan, and Shahidur R. Khandker. 2009. Handbook on Poverty and 
Inequality.Washington, DC: World Bank.

Hill, Hal. 2008. 'Globalization, Inequality, and Local-Level Dynamics: Indonesia and the Philippines. Asian Economic Policy Review 3 (1): 42-61.

Hill, Hal, Budy P. Resosudarmo, and Yogi Vidyattama. 2008. 'Indonesia's Changing Economic Geography'.Bulletin of Indonesian Economic Studies 44 (3): 407-35.

Howes, Stephen, and Robin Davies. 2014. 'Survey of Recent Developments'.Bulletin of Indonesian Economic Studies 50 (2): 157-83.

Leigh, Andrew, and Pierre van der Eng. 2009. 'Inequality in Indonesia: What Can We Learnfrom Top Incomes?'.Journal of Public Economics 93 (1-2): 209-12.

Manning, Chris, and Devanto S. Pratomo. 2013. 'Do Migrants Get Stuck in the Informal Sector? Findings from a Household Survey in Four Indonesian Cities'.Bulletin of IndonesianEconomic Studies 49 (2): 167-92.

Nugraha, Kunta, and Phil Lewis. 2013. 'Towards a Better Measure of Income Inequality in Indonesia'.Bulletin of Indonesian Economic Studies 49 (1): 103-12. Piketty, Thomas. 2014. Capital in the Twenty-First Century, translated by Arthur Goldhammer.Cambridge, MA: Harvard University Press.

Ravallion, Martin, and Shaohua Chen. 2003. 'Measuring Pro-poor Growth'.In Economics Letters 78 (1): 93-99.

Sakamoto, Hiroshi. 2007. 'The Dynamics of Inter-Provincial Income Distribution in Indonesia'.ICSEAD Working Paper 2007-25. Kitakyushu: The International Centre for theStudy of East Asian Development.

Skoufias, Emmanuel. 2001. 'Changes in Regional Inequality and Social Welfare in Indonesia from 1996 to 1999'. Journal of International Development 13 (1): 73-91. Sumner, Andy, and Peter Edward. 2014. 'Assessing Poverty Trends in Indonesia by International Poverty Lines'. Bulletin of Indonesian Economic Studies 50 (2): 207-25 
Suryadarma, Daniel, Rima Prama Artha, Asep Suryahadi, and Sudarno Sumarto. 2005. 'A Reassessment of Inequality and Its Role in Poverty Reduction in Indonesia'. SMERU Research Institute Working Paper. Jakarta: SMERU Research Institute. Suryadarma, Daniel, Wenefrida Widyanti, Asep Suryahadi, and Sudarno Sumarto. 2006. 'From Access to Income: Regional and Ethnic Inequality in Indonesia’. SMERU Research Institute Working Paper. Jakarta: SMERU Research Institute.

Suryahadi, Asep, Gracia Hadiwidjaja, and SudarnoSumarto. 2012. 'Economic Growth and Poverty Reduction in Indonesia before and after the Asian Financial Crisis'. Bulletin of Indonesian Economic Studies 48 (2): 209-27.

UNDP (United Nations Development Programme). 2014. Humanity Divided:

Confronting Inequality in Developing Countries. New York: UNDP.

Van der Eng, Pierre. 2009. 'Growth and Inequality: The Case of Indonesia, 19601997'.MPRA Paper 12725. Munich: Munich Personal RePEc Archive.

Van Leeuwen, Bas, and Peter Foldvari. 2012. 'The Development of Inequality and Povertyin Indonesia, 1932-1999. CGEH Working Paper 26. Utrecht: Center for Global EconomicHistory, Utrecht University.

Yusuf, Arief A., Ahmad Komarulzaman, M. Purnagunawan and Budy P.

Resosudarmo. 2013. 'Growth, Poverty, and Labor Market Rigidity in Indonesia: A General Equilibrium Investigation'. Working Paper in Economics and Development Studies 201304.Bandung: Department of Economics, Padjadjaran University. Yusuf, Arief Anshory, and Budy P. Resosudarmo. 2008. 'Mitigating Distributional Impact of Fuel Pricing Reform: The Indonesian Experience. ASEAN Economic Bulletin 25 (1):32-47. 
FIGURE 1 Gini Coefficient by Urban and Rural Areas of Indonesia, 1993-2013

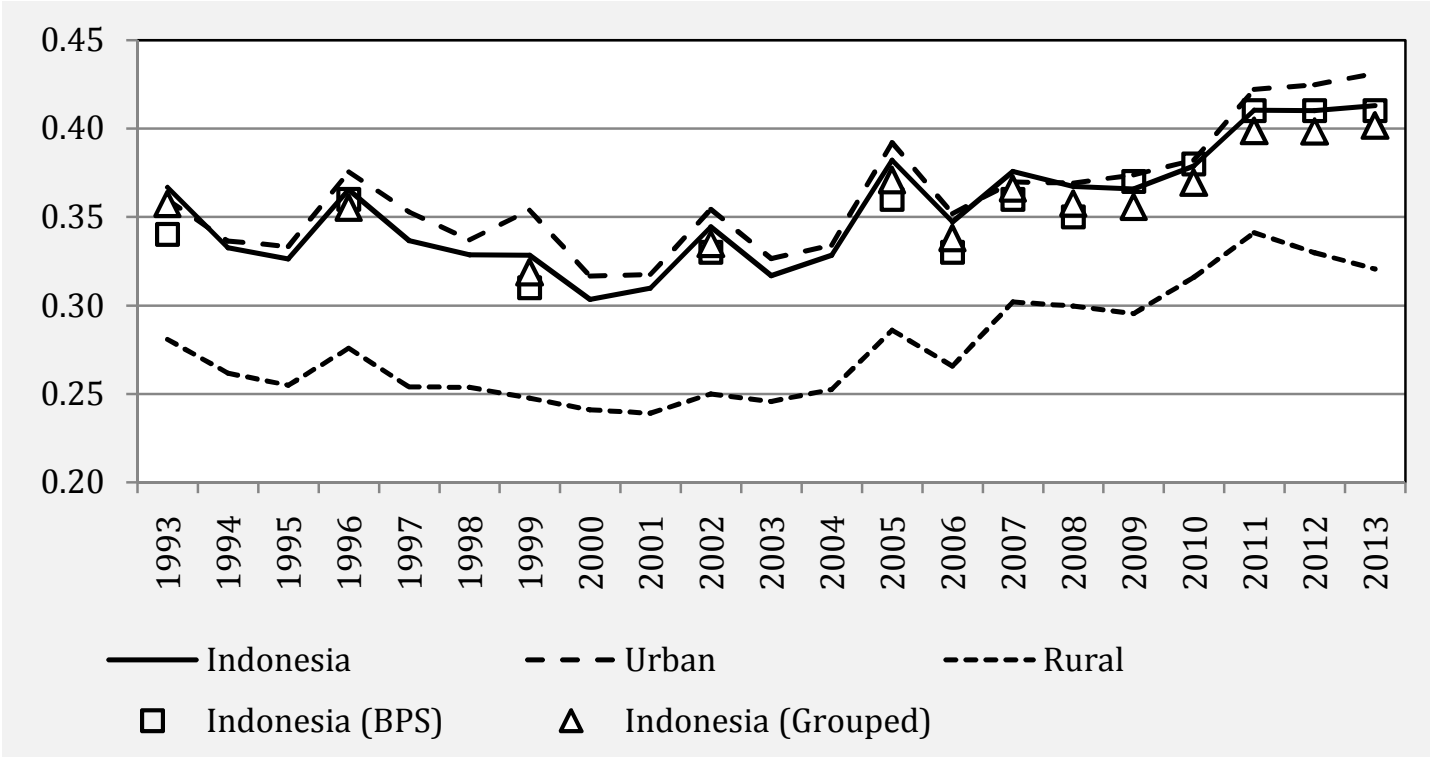

Source: Authors' calculations based on data from the National Socio-economic Survey (Susenas).

FIGURE 2 Lorenz Curves for 1993, 2003, and 2013

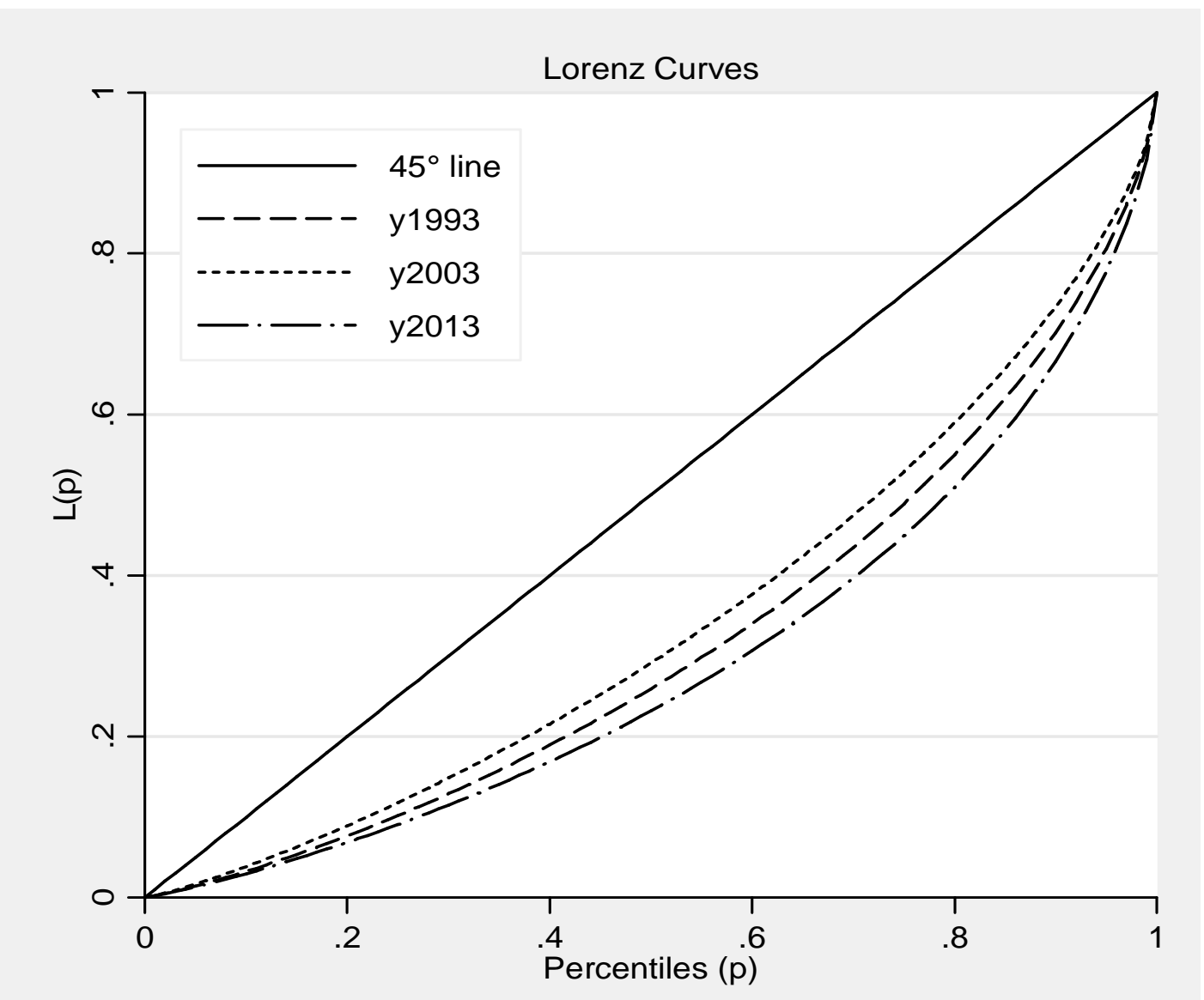

Source: Authors' calculations based on data from the National Socio-economic Survey (Susenas). 
FIGURE 3 Gini Coefficient in Java and Non-Java, 1993-2013
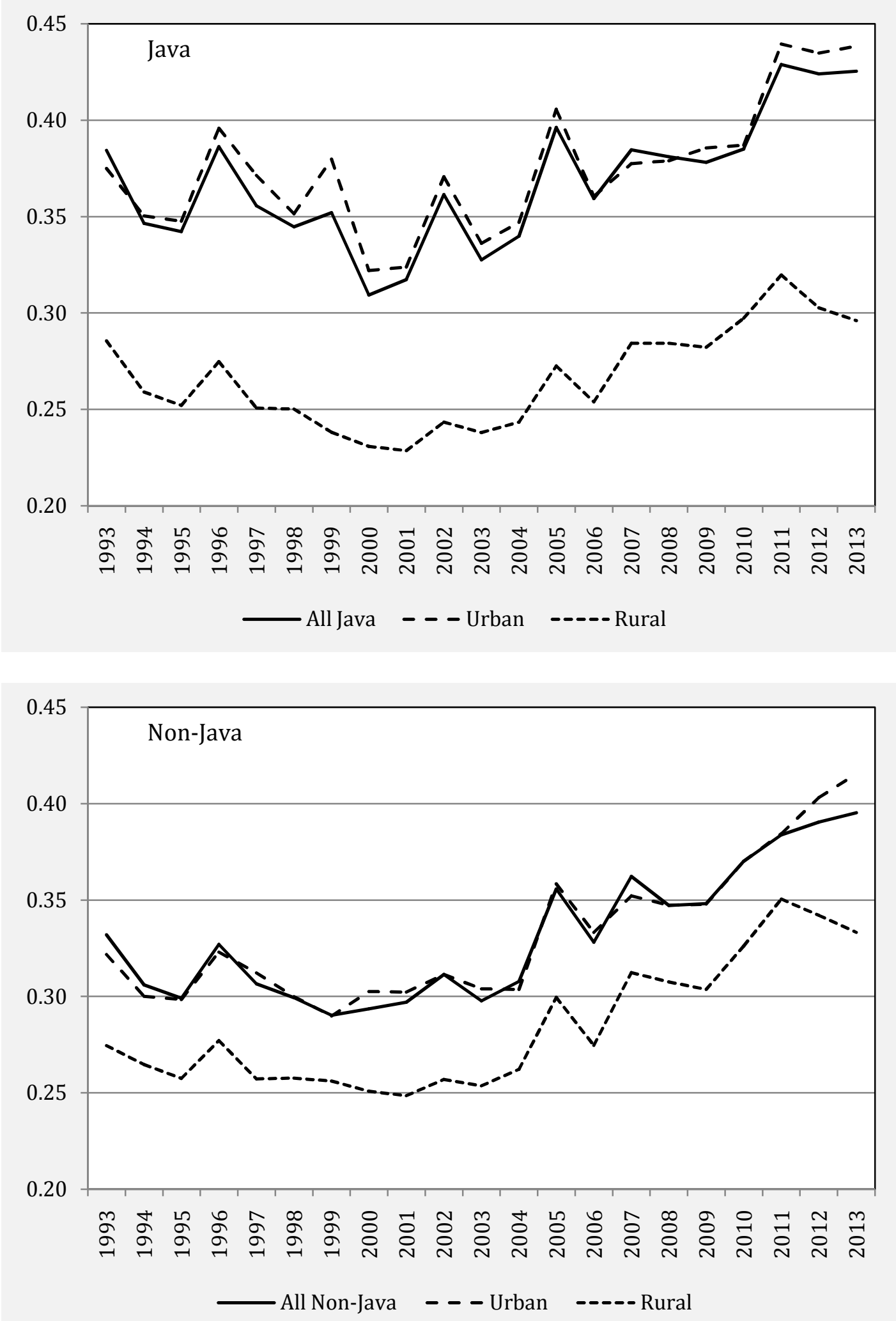

Source: Authors' calculations based on data from the National Socio-economic Survey (Susenas). 
FIGURE 4 Inequality Convergence across Indonesian Provinces (2003-13) and Districts (2002-12) (annual change; \%)

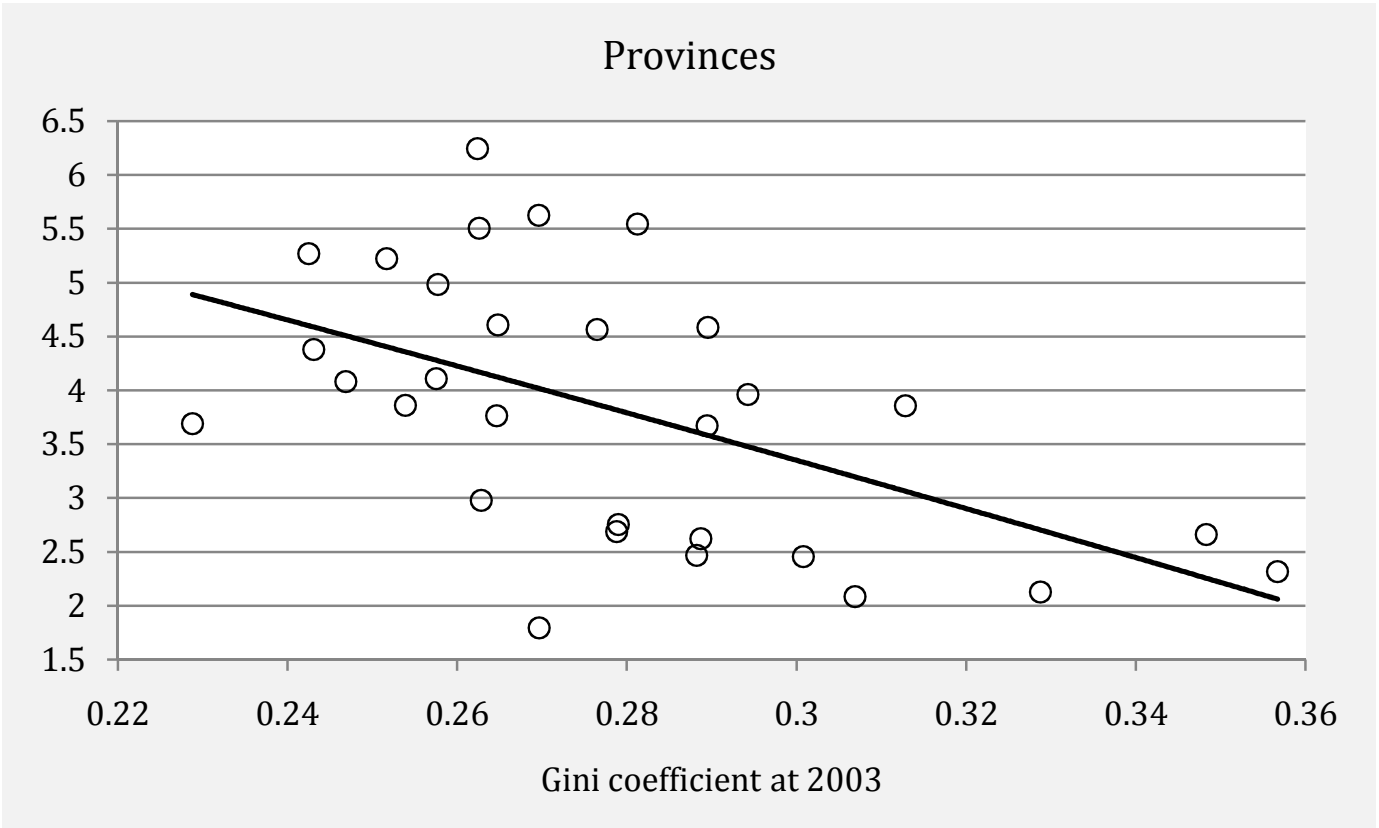

\section{Districts}

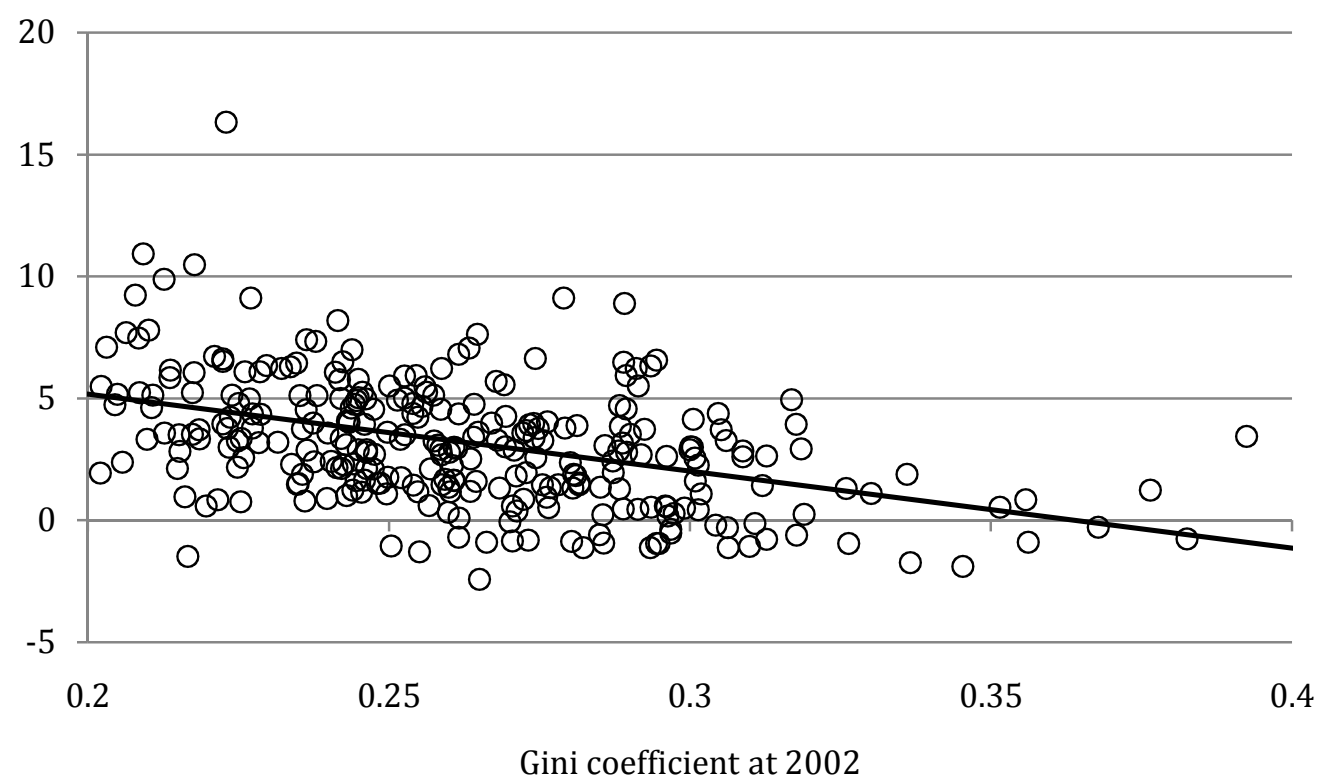

Source: Authors' calculations based on data from the National Socio-economic Survey (Susenas).Note: 2003-13 data used for provinces and 2002-12 data used for districts, owing to sample size in 2013. 
FIGURE 5 Ratio of Mean Expenditure of 10\% Richest to 10\% Poorest Households, 1993-2013

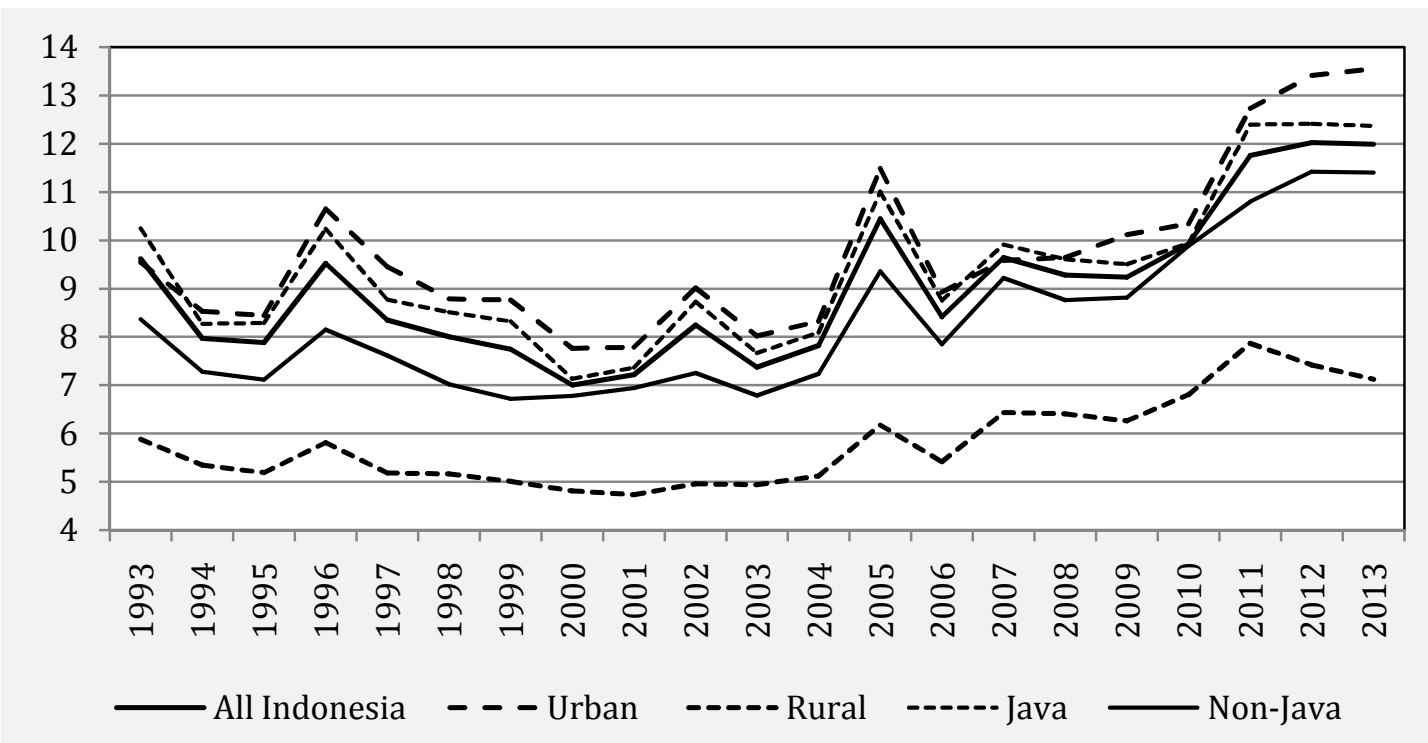

Source: Authors' calculations based on data from the National Socio-economic Survey (Susenas).

FIGURE 6 Theil Index of Interregional Inequality, 1993-2013

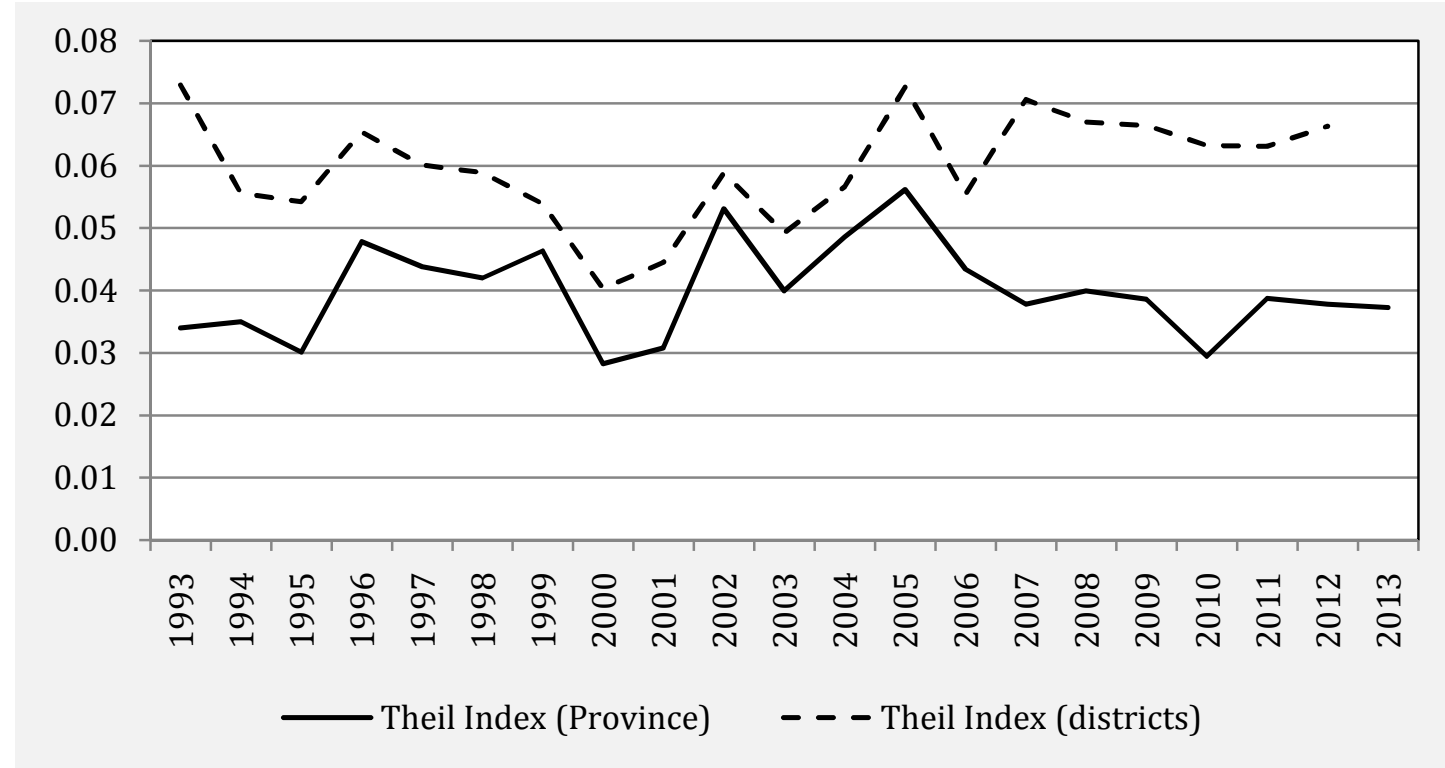

Source: Authors' calculations based on data from the National Socio-economic Survey (Susenas). 
FIGURE 7 Share of Inequality (Generalised Entropy) Explained byWithin-Region Inequality, 1993-2013(\%)

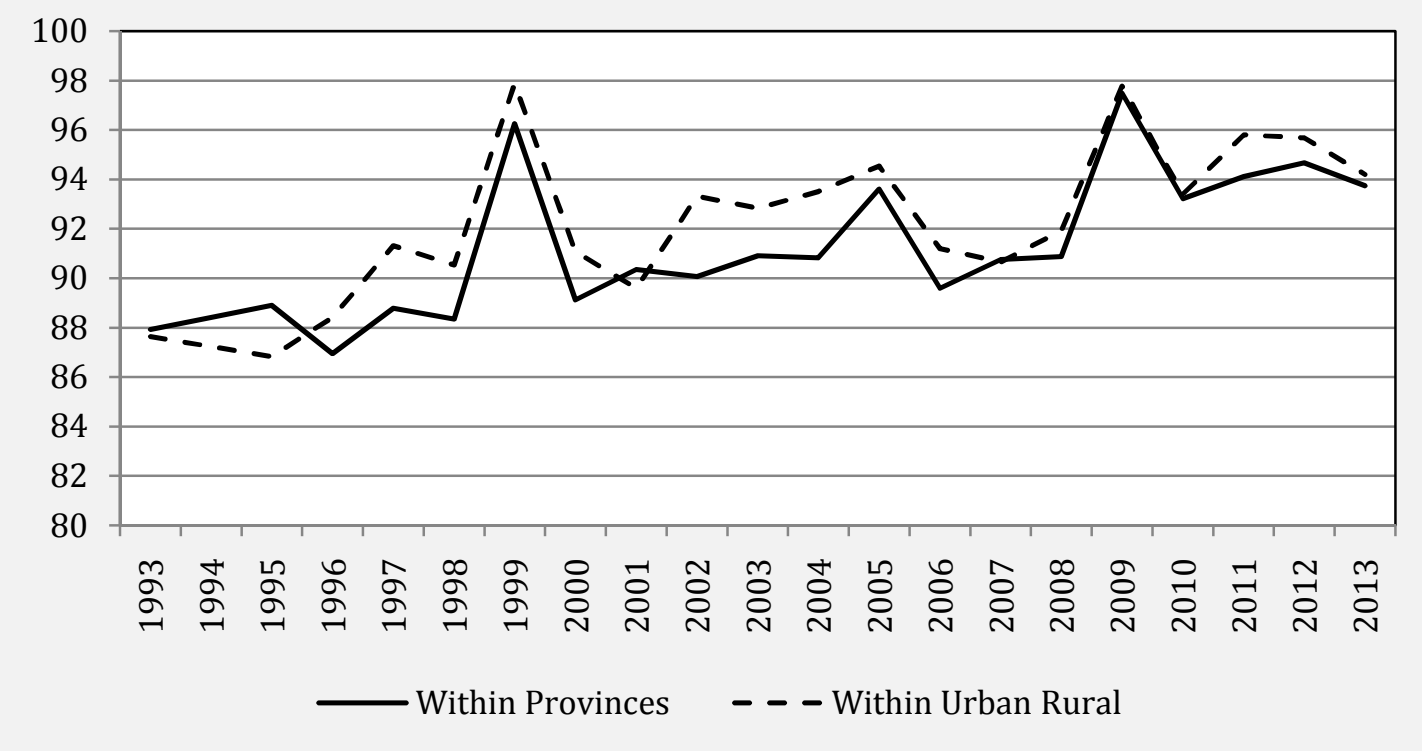

Source: Authors' calculations based on data from the National Socio-economic Survey (Susenas).

TABLE 1 Indonesia's Rates of Pro-poor Growth, 1990-2013(annual, average; \%)

\begin{tabular}{|c|c|c|c|c|c|c|c|c|}
\hline Years covered & \multicolumn{2}{|c|}{$1993-2013$} & \multicolumn{2}{|c|}{ 1990-1996 } & \multicolumn{2}{|c|}{ 1993-2003 } & \multicolumn{2}{|c|}{$2003-2013$} \\
\hline \multicolumn{9}{|c|}{ Rate of expenditure growth per capita (average, annual) } \\
\hline Growth rate in mean of population & 3.69 & 1.00 & 3.50 & 1.00 & 2.01 & 1.00 & 5.40 & 1.00 \\
\hline Growth rate at median of population & 3.23 & 1.14 & 2.59 & 1.35 & 2.72 & 0.74 & 3.74 & 1.44 \\
\hline Mean percentile growth rate & 3.39 & 1.09 & 2.82 & 1.24 & 2.6 & 0.77 & 4.32 & 1.25 \\
\hline \multicolumn{9}{|c|}{ Rates of 'pro-poor growth' by various poverty lines and percentiles (average, annual) } \\
\hline National poverty line & 3.02 & 1.22 & 1.98 & 1.77 & 3.5 & 0.57 & 2.61 & 2.07 \\
\hline$\$ 2 /$ day poverty line & 3.20 & 1.15 & 2.56 & 1.37 & 2.91 & 0.69 & 2.74 & 1.97 \\
\hline 10th percentile & 3.22 & 1.15 & 1.94 & 1.80 & 3.72 & 0.54 & 2.71 & 1.99 \\
\hline 15th percentile & 3.17 & 1.16 & 1.99 & 1.76 & 3.67 & 0.55 & 2.68 & 2.01 \\
\hline 20th percentile & 3.14 & 1.18 & 2.04 & 1.72 & 3.61 & 0.56 & 2.68 & 2.01 \\
\hline 25th percentile & 3.12 & 1.18 & 2.08 & 1.68 & 3.55 & 0.57 & 2.69 & 2.01 \\
\hline 30th percentile & 3.11 & 1.19 & 2.12 & 1.65 & 3.49 & 0.58 & 2.72 & 1.99 \\
\hline
\end{tabular}

Source: Authors' calculations based on data from the National Socio-economic Survey (Susenas). Note: Figures in italics are the ratios of the growth rate in the mean population to the respective population groups. Methodology based on Ravallion and Chen (2003). 